\title{
Hak Kewarisan Cucu (Analisis Yurisprudensi Mahkamah Tinggi Syariah di Selangor, Malaysia dan Mahkamah Agung di Indonesia)
}

\author{
Hajar M. \\ Fakultas Syariah dan Ilmu Hukum UIN Sultan Syarif Kasim Riau \\ Jl. HR. Soebrantas No. 155 KM.15 Tampan Pekanbaru \\ hajaruin@yahoo.com
}

\begin{abstract}
The problems in this research are: first, how is grandchildren's inheritance right in the jurisdiction of Islamic Supreme Court in Selangor, Malaysia and Supreme Court in Indonesia? Second, how is the comparison of grandchildren's inheritance right in those two jurisdictions; and how is the pattern of the distribution of inheritance to grandchildren? This research used comparative approach. The discussion was presented in descriptive analysis. The data analysis was qualitative and normative-juridical. The findings show that: first, grandshildren's right mentioned in the old fiqh mujtahid is revised in figh of consitutions in Selangor and in Indonesia. Grandchildren's inheritance right, based on the jurisdiction in Selangor, is called as wajibah, and in Indonesia it is called as heir substitute (ahli waris pengganti). Second, there are both similarities and differences between those two jurisdictions. The one in Selangor is a result of ijtihad tatbiqi which is in line with Islamic law principles. Grandchildren from the male side whose parents pass away first will receive inheritance right. Grandchildren from female side do not receive any right. The portions that grandchildren receive can be governed in inheritance status or last will which maintains justice. The jurisdiction of grandchildren's inheritance right in Indonesia is resulted from customary law which is adopted from Netherland's civil law. It is a part of culture which is not based on religious principle (syahadat), is against justice principle, ijbari principles, is not in line with inheritance elements, and is against the priority principle and hijab.
\end{abstract}

Keywords: Grandchildren's inheritance rights, Islamic Supreme Court in Selangor, Supreme Court in Indonesia.

\begin{abstract}
Abstrak
Pokok permasalahan pada penelitian ini: pertama, bagaimana hak waris cucu dalam Yurisprudensi Mahkamah Tinggi Syariah di Selangor, Malaysia dan Mahkamah Agung di Indonesia? Kedua, bagaimana perbandingan hak waris cucu dari dua yurisprudensi dan bagaimana pola pendistribusian harta kepada cucu? Metode yang digunakan adalah comparative approach. Bahasannya disajikan secara deskriptif analitis, kemudian dianalisa secara kualitatif dan yuridis normatif. Hasil penelitian menyimpulkan bahwa: pertama, hak cucu yang tertutup dalam fiqh mujtahid terdahulu, diperbarui dalam figh perundang-undangan di Selangor dan di Indonesia. Hak waris cucu berdasarkan yurisprudensi di Selangor disebut wasiat wajibah, dan di Indonesia disebut dengan ahli waris pengganti. Kedua, terdapat persamaan dan perbedaan antara kedua yurisprudensi. Yurisprudensi hak waris cucu di Selangor merupakan hasil ijtihad tatbiqi yang sejalan dengan prinsip hukum Islam. Cucu dari pihak laki-laki yang kematian orang tuanya lebih dahulu menerima hak waris. Cucu dari pihak perempuan tidak diberi hak. Bagian yang diterima cucu dapat ditetapkan dalam status waris maupun wasiat sejalan dengan kemaslahatan dan keadilan. Yurisprudensi hak waris cucu di Indonesia bersumber dari hukum adat yang diadopsi dari hukum perdata Belanda dan merupakan budaya yang tidak dilandasi oleh keimanan (syahadat), bertentangan dengan prinsip keadilan, asas ijbari, tidak sejalan dengan unsur-unsur kewarisan dan juga bertentangan dengan prinsip keutamaan dan hijab.
\end{abstract}

Kata kunci: Hak waris cucu, mahkamah tinggi syariah di Selangor, mahkamah agung di Indonesia. 


\section{Pendahuluan}

Hukum waris Islam menetapkan bahwa cucu dihijab oleh anak laki-laki untuk mendapat harta warisan kakek dan nenek. Hal itu disebabkan karena cucu berada pada urutan kedua, sedangkan anak berada pada urutan pertama. Cucu dihubungkan oleh anak kepada pewaris, dan anak berhubungan langsung dengan pewaris. Dalam kitab Ahkam al-Mawarits menyebutkan bahwa: "Cucu itu terhalang oleh anak laki-laki dari si mayit; terhalang juga oleh bapaknya, karena dialah yang berhubungan langsung dengan si mayit; atau terhalang oleh pamannya, karena ia menjadi ashabah terdekat dengan si mayit'. ${ }^{1}$

Masalahnya muncul apabila ada diantara anak yang meninggal dunia lebih dahulu dari orang tuanya, sedangkan anak tersebut telah mempunyai keturunan. Sebagai ilustrasi dapat dicontohkan dalam bagan berikut ini:

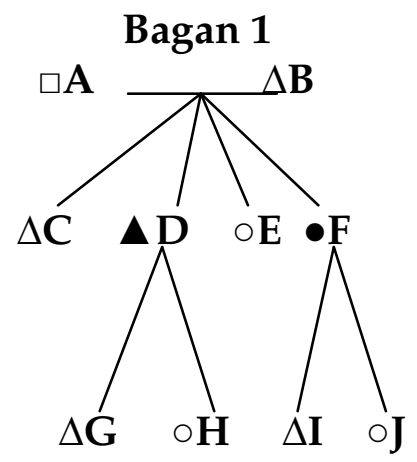

Maksud bagan, seorang nenek (B) meninggal dunia dengan meninggalkan suami/kakek (A), 2 orang anak laki-laki (E dan F), 2 orang anak perempuan (C dan D), serta 4 orang cucu (G, H, I dan J). Seorang anak laki-laki (F) dan seorang anak perempuan (D) telah meninggal lebih dahulu dari pewaris (B). D mempunyai 2 orang anak, laki-laki (H) dan perempuan (G). Demikian pula F meninggal lebih dahulu dari B, dan mempunyai anak, laki-laki (J) dan perempuan (I).

Berdasarkan contoh di atas, ahli waris yang mewarisi adalah A (suami) $1 / 4$ (25\%), seorang anak laki-laki (E) 2/4 (50\%), dan seorang anak perempuan (C) 1/4 (25\%). Adapun anak dari D dan F, yaitu H, G, J dan I tidak memperoleh apapun dari B (nenek) karena mereka dihijab oleh anak laki-laki (E).

${ }^{1}$ Komite Fakultas Syariah Universitas Al-Azhar, Abkam al-Mawarits fi al-Fiqh al-Islami, Cetakan 1, terj. Addys Aldizar dan Fathurrahman, Senayan Abadi Publishing, Jakarta, 2004, hlm. 283. 
Hak cucu yang terhijab mendapat perhatian serius bagi negara yang berpenduduk mayoritas muslim, terutama di Selangor Malaysia dan di Indonesia. Dalam Enakmen Wasiat Orang Islam Negeri Selangor Seksyen 27 memuat pembaruan hukum waris dan wasiat yang menyimpang dari madzhab Syafi'i. Cucu laki-laki dan cucu perempuan dari anak laki-laki, yang orang tuanya meninggal terlebih dahulu dari kakek/neneknya, maka ia diberi wasiat wajibah maksimal $1 / 3$. Besarnya wasiat untuk cucu disesuaikan dengan bahagian yang diterima ayahnya sekiranya masih hidup, selama tidak melebihi $1 / 3$ dari harta pewaris.

Mengenai Wasiat Wajibah ini, Jasni Sulong menulis: “Wasiyyat wajibah ialah wasiat yang dikuatkuasakan melalui peruntukan undang-undang bagi menjamin hak waris si mati yang terhalang daripada menerima pusaka karena penghubung mereka telah meninggal dunia terlebih dahulu" ${ }^{2}$

Di Indonesia, hak cucu yang terhijab tetap mendapat hak waris melalui ahli waris pengganti. Keberadaan ahli waris pengganti terdapat dalam Kompilasi Hukum Islam (KHI) Pasal 185. Cucu dapat mewarisi bersama anak laki-laki dan anak perempuan. Mereka tidak dapat ditutup oleh anak laki-laki, karena berkedudukaan menggantikan ayah atau ibu mereka yang telah meninggal lebih dahulu.

Hak waris cucu yang ditetapkan melalui enakmen di Selangor, Malaysia dan KHI di Indonesia diduga memiliki persamaan dan perbedaan. Di sisi lain, kedua yurisprudensi dari dua negara yang berbeda perlu dikaji ulang tentang sistem pemberian hak waris kepada cucu yang orang tua mereka meninggal lebih dahulu, baik ketika ada anak laki-laki maupun status cucu dari anak perempuan.

\section{Rumusan Masalah}

Berdasarkan fenomena yang dikemukakan di atas, permasalahan pada penelitian ini: Pertama, bagaimana hak waris cucu dalam Yurisprudensi Mahkamah Tinggi Syariah di Selangor, Malaysia dan Mahkamah Agung di

2Jasni Sulong, "Kedudukan Madzhab Syafi'i dalam Amalan Pembagian Pusaka dan Wasiat di Malaysia", dalam Shariah Journal, Vol. 16 Nomor 1, 2008, hlm. 180. 
Indonesia? Kedua, bagaimana perbandingan hak waris cucu dari dua yurisprudensi dan bagaimana pola pendistribusian harta kepada cucu?

\section{Tujuan Penelitian}

Penelitian ini bertujuan untuk mengetahui: pertama, hak waris cucu dalam Yurisprudensi Mahkamah Tinggi Syariah di Selangor, Malaysia dan Mahkamah Agung di Indonesia; kedua, perbandingan hak waris cucu dari dua yurisprudensi dan pola pendistribusian harta kepada cucu.

\section{Metode Penelitian}

Penelitian ini menggunakan pendekatan perbandingan (Comparative Approach), yaitu membandingkan yurisprudensi yang berbeda dalam kasus yang sama tentang hak waris cucu antara Indonesia dan Selangor, Malaysia. Penelitian ini berasal dari data sekunder, dengan menggunakan bahan hukum primer, (primary sources or authorities) berupa Enakmen Wasiat Orang Islam Negeri Selangor No. 4 Tahun 1999, Kompilasi Hukum Islam, Putusan hakim (yurisprudensi) Mahkamah Tinggi Syariah Negeri Selangor No. 10600-040-00642011, Putusan Mahkmah Agung Nomor 594 K/AG/2008, Putusan Hakim Pengadilan Tinggi Agama Pekanbaru Nomor 05/Pdt.G/2010/PTA.Pbr, dan sekunder (secondary sources or authorities). Data disajikan secara deskriptif analitis, kemudian dianalisa secara yuridis normatif.

\section{Hasil Penelitian dan Pembahasan}

\section{Hak Waris Cucu dalam Yurisprudensi di Selangor dan Indonesia}

Pedoman utama merumuskan perundang-undangan di Malaysia bertitik tolak pada madzhab Syafi'i. Sekiranya tidak terdapat dalam madzhab Syafi'i terhadap persoalan yang akan dirujuk atau tidak sesuai dengan keadaan masa sekarang dan kepentingan umum, maka barulah pandangan madzhab yang lain 
dapat dipertimbangkan. Jasni Sulong menyatakan: "Peruntukan undang-undang Islam di Malaysia menggariskan bahwa pemakaian pandangan Madzhab Syafi'i dalam pentadbiran undang-undang adalah mengutamakan Madzhab Syafi'i. Dalam arti kata, rujukan kepada sebarang keputusan, hukum dan pendirian agama adalah dengan memberi fokus terlebih dahulu kepada pandangan Madzhab Syafi'i. Sekiranya tiada pandangan dalam persoalan yang dirujuk itu atau tidak sesuai dengan keadaan masa dan kepentingan umum, maka barulah pandangan daripada madzhab yang lain diambil pertimbangan". ${ }^{3}$

Negeri Selangor merupakan yang pertama mewujudkan Undang-Undang Pentadbiran Hukum Syara' di Malaysia. Di antara undang-undang yang diwujudkan adalah Enakmen Wasiat Orang Islam. Enakmen ini telah dirumuskan dan diberlakukan oleh pemerintahan negeri. Draft Enakmen tersebut dirumuskan oleh pemerintah melalui Jabatan Kehakiman Syariah Negeri Selangor (JAKESS), dan selanjutnya diajukan dalam rapat parlemen untuk dibahas bersama wakil rakyat tersebut. Setelah disahkan dan mendapat persetujuan dari DiRaja, barulah diundang dan diberlakukan. Enakmen Wasiat Orang Islam Negeri Selangor ini No. 4 Tahun 1999 yang telah diundangkan pada 30 September 1999, dan mulai diberlakukan sejak 1 Juli 2004. Seksyen 27 berbunyi:

(1). Where a person dies without making any will to his grandchildren throught his son who has predeceased him or dies with him at the same time, then hid grandchildren shall be entitled to the will of one-third of his estate and, if such grandchildren is given less than one-third, his share shall be executed in accordance with the provisions of the obligatory will provided for under this section.

(2). The obligatory will for the grandchildren shall be to the extent of their father's share in the estate of his deceased grandfather, presuming that the father died after the death of the grandfather. Provided that the will shall not exceed one-third og the deceased's estate.

(3). The grandchildren shall not be entitled to the bequest if they inherited from their grandfather or grandmother, as the cae may be, or if the grandfather or grandmother had, during his or her lifetime and without having received any consideration, made a will to them or gave them a property equivalent to what they would have been entitled according to the obligatory will; Provided that if the will is less than what they would have been entitled, it shall be increased accordingly and, if it was more, the excess shall be treated as voluntary will which is subject to the consent of heirs".

Seksyen 27 di atas menetapkan bahwa cucu dari anak laki-laki, yang orang tuanya meninggal terlebih dahulu, diberi wasiat wajibah maksimal $1 / 3$ dari harta 
warisan. Minimal disesuaikan dengan bahagian yang bakal diterima oleh ayahnya sekiranya ayah mereka masih hidup, selama tidak melebihi $1 / 3$ dari harta pewaris.

Zamro memberi contoh tentang wasiat wajibah, yaitu Yusuf meninggal terlebih dahulu dari ayahnya (Muhammad). Yusuf mempunyai dua orang anak yaitu Azizah dan Azhar, sedangkan Muhammad masih mempunyai dua orang anak yang masih hidup yaitu Rahim dan Musa. Ketika Muhammad meninggal, Azizah dan Azhar menerima wasiat wajibah, karena kedua cucunya ini telah kematian ayah sebelum kakeknya meninggal. ${ }^{4}$ Untuk lebih jelas dapat diperhatikan bagan berikut:

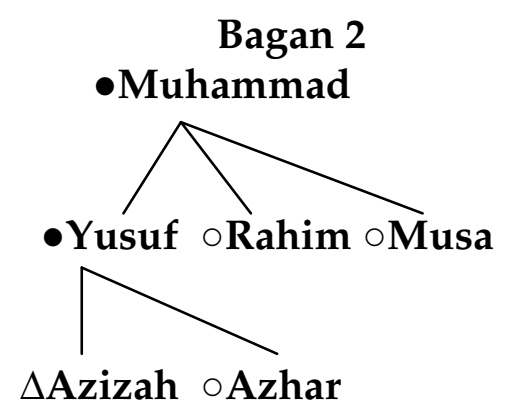

Wan Abdul Halim memberi contoh penyelesaian kasus wasiat wajibah menurut Enakmen dan madzhab Syafi'i. Jika seseorang meninggal, meninggalkan dua anak laki-laki dan seorang anak perempuan yang masih hidup, serta ada seorang anak laki-laki yang meninggal terlebih dahulu. Anak yang meninggal terlebih dahulu itu mempunyai dua anak laki-laki. Sijil Farâidh yang dikeluarkan menurut wasiat wajibah adalah: a. Seorang anak laki-laki pertama mendapat $2 / 7$; b. Seorang anak laki-laki kedua mendapat $2 / 7$; c. Seorang anak perempuan mendapat $1 / 7$; d. Seorang cucu laki-laki pertama mendapat $1 / 7$; e. Seorang cucu laki-laki kedua menerima $1 / 7.5$

Kedua cucu laki-laki dari anak laki-laki yang meninggal terlebih dahulu mendapat harta peninggalan melalui wasiat wajibah. Bagi masyarakat yang tidak memberlakukan Enakmen, karena mengikuti madzhab Syafi'i, maka penyelesaian kasus tersebut adalah: a. Seorang anak laki-laki pertama mendapat $2 / 5 ; b$.

${ }^{4}$ Mohd. Zamro Muda, "Instrumen Hibah dan Wasiat: Analisis Hukum dan Aplikasinya di Malaysia", Kertas kerja dibentangkan di Bengkel Hibah, Seksyen Syariah Jabatan Peguam Negara, Hotel Equatonial, 18-19 November 2008, hlm. 29.

5Wan Abdul Halim bin Wan Harun, "Isu-Isu Pembahagian Harta Pusaka dalam Konteks Perundangundangan", dalam Pengurusan Jawhar, Vol. 3 No. 1, 2009, hlm. 178. 
Seorang anak laki-laki kedua mendapat $2 / 5$; c. Seorang anak perempuan mendapat $1 / 5$; d. Dua cucu laki-laki tidak mendapat sama sekali karena dihijab oleh paman atau saudara ayah mereka.

Berdasarkan contoh di atas, terlihat jelas bahwa bila masyarakat menerapkan enakmen, maka cucu yang kematian ayah terlebih dahulu mendapat harta warisan melalui wasiat wajibah. Jika tetap memilih madzhab Syafi'i, kedua cucu tersebut dihijab oleh paman mereka sehingga tidak mendapat harta warisan.

Adapun contoh kasus waris cucu sebagai penerima wasiat wajibah yang telah diajukan dan diputuskan oleh Mahkamah Tinggi Syariah Negeri Selangor adalah kasus nomor: 10600-040-0064-2011 yang diajukan oleh Mohd. Sapran bin Hosnan, dengan meninggalnya Hosnan bin Siraj nomor kematian: D. 776401 tanggal 18 Januari 2011. Hosnan bin Siraj mempunyai delapan orang anak, yaitu Mohd. Sapran bin Hosnan (laki-laki), nomor KP. 670531-01-6005, Humari bin Hosnan (laki-laki), nomor KP. 540827-01-5751, Mohd. Anim bin Hosnan (lakilaki), nomor KP. 590111-01-5433, Wahid bin Hosnan (laki-laki), nomor KP. 5111040-01-5835, Rosnah binti Hosnan (perempuan), nomor KP. 560918-01-5464, Anisah binti Hosnan (perempuan), nomor KP. 620224-01-5656, Zarinah binti Hosnan (perempuan), nomor KP. 650101-01-8862, Nuazian binti Hosnan (perempuan), nomor KP. 721018-01-5068, dan seorang isteri bernama Warta binti Mokri, nomor KP. 350124-01-5168.

Wahid bin Hosnan meninggal terlebih dahulu dari ayahnya Hosnan bin Siraj pada tanggal 9 September 2007, dengan meninggalkan tiga orang anak perempuan yaitu Norwahidah binti Wahid, nomor KP. 781101-01-5898, Norazida binti Wahid, nomor KP. 840225-01-5994, dan Noratika binti Wahid, nomor KP. 890325-01-6092.

Berdasarkan kuasa yang diberikan oleh Seksyen 65 Enakmen Pentadbiran Agama Negeri Selangor tahun 2003 untuk memberlakukan Enakmen Wasiat Orang Islam Selangor, Seksyen 27, maka putusan faraidh atas harta pusaka yang dimohon oleh Mohd. Sapran bin Hosnan adalah sebagai berikut: 1) Mohd. Sapran bin Hosnan (anak laki-laki) menerima $672 / 4320$; 2) Humari bin Hosnan (anak lakilaki) menerima $672 / 4320$; 3) Mohd. Anim bin Hosnan (anak laki-laki) menerima $672 / 4320$; 4) Rosnah binti Hosnan (anakn perempuan) menerima $336 / 4320$; 5) 
Anisah binti Hosnan (anakn perempuan) menerima 336/4320 ; 6) Zarinah binti Hosnan (anakn perempuan) menerima 336/4320 ; 7) Nuraizan binti Hosnan (anakn perempuan) menerima 336/4320 ; 8) Warta bint Mokri (isteri) mendapat 540/4320 ; 9) Norwahidah binti Wahid (cucu perempuan) menerima wasiat wajibah sebesar $140 / 4320 ; 10$ ) Norazida binti Wahid (cucu perempuan) menerima wasiat wajibah sebesar $140 / 4320$; 11) Noratika binti Wahid (cucu perempuan) menerima wasiat wajibah sebesar $140 / 4320 \cdot 6$

Penyelesaian kasus di atas, wasiat wajibah yang diterima cucu $420 / 4320$ atau kurang dari $1 / 10$ harta warisan. Bahkan jauh berkurang dari saham yang diterima saudara ayah (paman) mereka, yaitu 672/4320. Berkurangnya harta warisan yang diperoleh cucu sebagai penerima wasiat wajibah merupakan bentuk kehati-hatian hakim dalam memutuskan perkara wasiat. Hakim masih mempertimbangkan hak anak karena madzhab Syafi'i bahwa anak laki-laki menghijab cucu secara penuh. Hal ini berarti bahwa pihak mahkamah belum sepenuhnya menerapkan wasiat wajibah karena masih mempertimbangkan kesadaran hukum masyarakat yang ber madzhab Syafi'i.

Selain itu, wasiat wajibah hanya diberikan kepada cucu laki-laki dan cucu perempuan dari anak laki-laki saja. Cucu perempuan dan cucu laki-laki dari anak perempuan tidak mendapat wasiat wajibah, karena mereka bukan ahli waris dalam kewarisan ahlu sunnah, tetapi sebagai dzawū al-arhām.

Wasiat wajibah yang diberlakukan melalui Enakmen Wasit Orang Islam adalah untuk menjamin hak waris cucu yang tidak dapat menerima hak kewarisan, karena penghubung mereka telah meninggal terlebih dahulu. Mahmud menyatakan bahwa: "Kaedah ini berasal dari pandangan Ibnu Hazm untuk menghindari kezaliman terhadap cucu yang tidak mendapat harta warisan karena si mayit tidak meninggalkan wasiat". ${ }^{\prime}$

Sekiranya kakek atau nenek memelihara seorang atau beberapa orang cucu dari anak perempuan yang telah meninggal terlebih dahulu, cucu tersebut tidak akan menerima wasiat wajibah apalagi menerima harta warisan. Bila hal ini terjadi, berarti suatu kelemahan dalam pentadbiran undang-undang Islam yang bertujuan

${ }^{6}$ Arsip Putusan diperoleh dari Mahkamah Tinggi Syariah di Selangor, Malaysia, Tahun 2013.

${ }^{7}$ Mahmud Muhammad Badly, Pengurusan dan Penyelewengan Harta dalam Pandangan Islam, Dinie Publisher, Kuala Lumpur, 1994, hlm. 113. 
untuk memastikan kebaikan kepada ahli waris. Jika cucu tersebut telah menjaga dan merawat kakek dan neneknya itu sampai meninggal, sedangkan cucu itu ditinggalkan tanpa harta dan ahli waris, maka hal itu merupakan kenistaan.

Ahmad Ibrahim menyatakan, bahwa wasiat wajibah ini berasal dan merupakan aspek pembaruan hukum Islam di negara-negara Arab. ${ }^{8}$ Di Mesir misalnya, wasiat wajibah dimasukkan ke dalam perundang-undangan untuk menjamin adanya hak cucu yang kematian ayah dan tertutup oleh anak pewaris (paman). Selain di Mesir, wasiat wajibah juga dijadikan perundang-undangan di Sudan, Suriah, Maroko, dan Tunisia. Di Suriah dan Maroko, cucu yang berhak tersebut hanyalah cucu melalui anak laki-laki saja. Cucu melalui anak perempuan tetap tidak berhak. Sedangkan di Tunisia, wasiat wajibah hanya berlaku untuk semua cucu keturunan pertama (first generation). ${ }^{9}$

Hak kewarisan cucu dalam Yurisprudensi Mahkamah Agung di Indonesia bersumber dari Kompilasi Hukum Islam (KHI). Penyusunan KHI periode terakhir di Indonesia dimulai pada 1983, yaitu sejak penandatanganan Surat Keputusan Bersama (SKB) Ketua Mahkamah Agung RI dan Menteri Agama RI tentang penunjukan pelaksana proyek pembangunan hukum Islam melalui yurisprudensi, guna keseragaman dan menjadi rujukan para hakim pada pengadilan Agama. Panitia bekerja selama lebih kurang lima tahun, dan pada tahun 1988 rumusan KHI siap untuk diajukan kepada pemerintah menuju legalitas perundang-undangan. Menurut Abdurrahman, selama tiga tahun lebih menunggu tindak lanjut rancangan KHI, akhirnya Presiden Soeharto menandatangani Instruksi Presiden Nomor 1 tanggal 10 Juni 1991.10

Di antara latar belakang munculnya KHI, karena tidak ada keseragaman dalam menetapkan hukum Islam, belum mampu menggunakan UUD 1945 dan tidak jelas tata cara melaksanakan hukum Islam. Basran menyatakan: 1) Ketidakseragaman dalam menentukan apa-apa yang disebut dengan hukum Islam itu; 2) Ketidakjelasan bagaimana melaksanakan syariah Islam itu; 3) Akibat yang lebih jauh lagi, adalah kita tidak mampu mempergunakan jalan-jalan

\footnotetext{
${ }^{8}$ Ahmad Ibrahim, Undang-Undang Keluarga Islam di Malaysia, Lexis Nexis, Kuala Lumpur, 2011, hlm. 9. hlm. 20 .

${ }^{9}$ Abdullah Siddik, Hukum Waris Islam dan Perkembangannya di Selurub Dunia Islam, Wijaya, Jakarta, 1984,

${ }^{10}$ Abdurrahman, Kompilasi Hukum Islam di Indonesia, Akademika Pressindo, Jakarta, 2004, hlm. 55-56.
} 
dan alat-alat yang telah tersedia dalam UUD 1945 dan perundang-undangan lainnya".11

Usaha yang ditempuh dalam proses penyusunan $\mathrm{KHI}$ adalah pengkajian kitab, yurisprudensi, studi perbandingan, wawancara dan lokakarya. Ahmad Rofiq menyebutkan:

"Bahwa usaha-usaha yang ditempuh adalah melalui jalur-jalur sebagai berikut: (a). Pengkajian kitab-kitab figh, (b). Wawancara dengan para ulama, (c). Yurisprudensi Pengadilan Agama, (d). Studi perbandingan hukum dengan Negara lain, (e). Lokakarya/seminar materi hukum untuk Pengadilan Agama"..12

KHI memuat pembaruan hukum kewarisan. Di antaranya keberadaan ahli waris pengganti. Pasal $185 \mathrm{KHI}$ menyebutkan:

(1). "Ahli waris yang meninggal lebih dahulu dari pada si pewaris maka kedudukannya dapat digantikan oleh anaknya, kecuali mereka yang tersebut dalam Pasal 173". (2). "Bagian ahli waris pengganti tidak boleh melebihi dari bagian ahli waris yang sederajat dengan yang diganti".

Isi pasal di atas, cucu dapat mewarisi bersama anak laki-laki dan anak perempuan. Mereka tidak dapat ditutup oleh anak laki-laki, karena berstatus menggantikan ayah atau ibu mereka yang telah meninggal lebih dahulu. Misalnya Putusan Mahkamah Agung dalam perkara Nomor 594 K/AG/2008 tanggal 16 Januari 2009. Penggugat dalam tingkat kasasi adalah H. Mansyurdin melawan Nur Syofia Ulfa, SE, dkk sebagai tergugat dan turut tergugat. Salah satu gugatan yang diajukan adalah memohon penetapan adanya ahli waris pengganti. Permohonan ahli waris pengganti ini disebabkan salah seorang anak almarhumah Hj. Nuraini Saleh, SH, yaitu dr. Nur Ismi Faruni meninggal terlebih dahulu dengan meninggalkan seorang anak perempuan bernama Pranaya Astita. Hakim Mahkamah Agung memutuskan dan menetapkan ahli waris dan bagian masing-masing sebagai berikut: 1) $\mathrm{H}$. Mansyurdin (suami dari almarhumah Hj. Nuraini Saleh, SH) mendapat 2/8 bagian; 2) Nur Syofia Ulfa, SE (anak perempuan) mendapat 1/8 bagian; 3) Rinaldy Aris Mauludin, SE (anak laki-laki) mendapat 2/8 bagian; 4) Liliy Kusuma Wardhani, ST (anak perempuan) mendapat $1 / 8$ bagian; 5) Ulfia Damayanti Agustini, ST (anak perempuan) mendapat $1 / 8$ bagian; 6) Pranaya Astuti, yaitu anak dari dr. Nur Ismi Faruni. dr. 
Nur Ismi Faruni meninggal terlebih dahulu dari Ibunya Hj. Nur Aini Saleh, SH, sehingga Pranaya Astuti berkedudukan sebagai ahli waris pengganti menggantikan kedudukan ibunya mendapat $1 / 8$ bagian. ${ }^{13}$

Dari penyelesaian kasus di atas, hakim menerapkan Pasal $185 \mathrm{KHI}$, tidak hanya pada tingkat kasasi, tetapi juga pada pengadilan tingkat pertama (Pengadilan Agama Pekanbaru) dan pada tingkat banding (Pengadilan Tinggi Agama Pekanbaru). Hal ini menunjukkan bahwa pada setiap tingkatan peradilan, hakim tetap memberlakukan Pasal 185 KHI dalam peristiwa munculnya ahli waris pengganti. Bagian yang diterima oleh ahli waris pengganti adalah sebesar bagian ahli waris yang digantikannya.

Demikian pula Putusan Hakim Pengadilan Tinggi Agama Pekanbaru Nomor 05/Pdt.G/2010/PTA.Pbr., tanggal 25 Februari 2010. Penggugat dalam tingkat banding adalah Katidjem binti Matrejo melawan Ardem bin Mardenis Ahmat dkk (13 orang). Perkaranya berawal dari meninggalnya Ahmat bin Mulut, dengan meninggalkan dua orang isteri, dan dua orang anak laki-laki. Seorang anak laki-laki bernama Mardenis bin Ahmat bin Mulut meninggal terlebih dahulu dari ayahnya (Ahmat bin Mulut) dengan meninggalkan 12 (dua belas) orang anak, laki-laki dan perempuan.

Hakim Pengadilan Tinggi Agama Pekanbaru menetapkan ahli waris Ahmat bin Mulut, dan bagian mereka masing-masing sebagai berikut:

1) Dua orang isteri yaitu Hj. Mariana binti Kiman dan Katidjem binMatrejo mendapat $1 / 8$, masing-masing menerima $1 / 16$ bagian yaitu $17 / 272(6,25 \%)$; 2) Aljumrak bin Ahmat (anak laki-laki) menerima sisa ('ashabah) yaitu $7 / 16$ bagian atau 119/272 (43,75\%); 3) Ardem bin Mardenis, cucu laki-laki dari anak laki-laki pewaris sebagai ahli waris pengganti menerima $14 / 272$ bagian atau $(5,15 \%)$; 4) Damra bin Mardenis, cucu laki-laki dari pewaris (ahli waris pengganti) mendapatkan $\mathbf{1 4} / \mathbf{2 7 2}$ bagian atau $(5,15 \%)$; 5$)$ Darmarita binti Mardenis, cucu perempuan sebagai ahli waris pengganti mendapat $7 / 272$ bagian atau $(2,57 \%)$; 6) Armaida binti Mardenis, cucu perempuan sebagai ahli waris pengganti mendapat $7 / 272$ bagian atau (2,57\%); 7) Radesma binti Mardenis, cucu perempuan sebagai ahli waris pengganti mendapat $7 / 272$ bagian atau (2,57\%); 8) Winda Yuliani binti Mardenis, cucu perempuan sebagai ahli waris pengganti mendapat $7 / 272$ bagian atau (2,57\%); 9) Alex Saputra binti Mardenis, cucu laki-laki sebagai ahli waris pengganti mendapat $14 / 272$ bagian atau $(5,15 \%)$; 10) Fitriyani binti Mardenis, cucu perempuan sebagai ahli waris pengganti mendapat $7 / 272$ bagian atau $(2,57 \%)$; 11) Fitriyanti binti Mardenis, cucu perempuan sebagai ahli waris pengganti mendapat $7 / 272$ bagian atau $(2,57 \%)$; 12) Damris binti Mardenis, cucu laki-laki sebagai ahli waris pengganti mendapat 14/272 bagian atau $(5,15 \%)$; 13) Rusmini binti Mardenis, cucu

${ }^{13}$ Arsip putusan pada Mahkamah Agung RI., tahun 2009. 
perempuan sebagai ahli waris pengganti mendapat $7 / 272$ bagian atau (2,57\%);

14) Amhar binti Mardenis, cucu laki-laki sebagai ahli waris pengganti mendapat $14 / 272$ bagian atau $(5,15 \%)$.

Kedudukan ahli waris pengganti dalam contoh kasus di atas adalah menggantikan orang tua mereka yang telah meninggal terlebih dahulu dari pewaris. Hak yang mereka terima adalah hak kewarisan yang semestinya diterima oleh orang tua mereka yang telah mati, namun dianggap di masih hidup, dan haknya itu diserahkan kepada anak-anaknya (cucu pewaris). Cucu laki-laki menerima hak dua kali dari yang diterima cucu perempuan. Cucu sebagai ahli waris pengganti tidak dibedakan antara cucu pihak laki-laki dan cucu pihak perempuan.

Kehadiran ahli waris pengganti dalam KHI dirumuskan melalui jalur yurisprudensi yang bersumber dari hukum adat. Ahli waris pengganti dalam hukum adat merupakan adopsi dari hukum perdata $(B W)$ Belanda. Sedangkan hukum perdata Belanda berasal dari Code Civil Napoleon di Perancis. Hukum perdata Perancis merupakan turunan dari hukum Romawi.

Di sisi lain, ahli waris pengganti dalam KHI sama sebagaimana dikemukakan oleh Hazairin. Beliau berdalih bahwa ahli waris pengganti bersumber dari al-Qurān surat an-Nisa' ayat 33.

\section{Perbandingan}

Apabila dihubungkan antara kedua yurisprudensi yang memuat konsep wasiat wajibah dan ahli waris pengganti, maka dapat ditarik suatu perbandingan berupa persamaan dan perbedaan. Aspek persamaannya adalah: a. Kedua peraturan merupakan pembaruan hukum dalam masyarakat yang selama ini menganut empat madzhab fiqh, terutama madzhab Syafi'I; b. Kedua peraturan samasama berupaya memberikan hak kepada cucu yang orang tua mereka meninggal terlebih dahulu dari pewaris; c. Kedua peraturan sama-sama berupaya untuk mewujudkan keadilan dalam perspektif masyarakat, khususnya dalam pendistribusian harta kakek dan nenek kepada cucu yang orang tuanya terlebih dahulu meninggal; d. Kedua peraturan sama-sama memberlakukan pembagian 2:1 antara cucu laki-laki dan cucu perempuan sebagaimana hukum kewarisan 
Islam; e. Kedua peraturan sama-sama mengabaikan kehadiran anak laki-laki pewaris yang masih hidup sehingga dia tidak dipandang menutup cucu.

Adapun segi-segi perbedaan dari kedua peraturan tersebut adalah: a. Pembaruan yang terdapat dalam kedua peraturan berbeda dalam konsep. Seksyen 27 memberi nama dengan wasiat wajibah, sedangkan Pasal 185 KHI menyebut ahli waris pengganti. Pada wasiat wajibah, cucu tidak dianggap sebagai ahli waris, tetapi berstatus sebagai penerima wasiat. Sedangkan ahli waris pengganti berarti bahwa cucu dipandang sebagai ahli waris dari kakek dan neneknya yang meninggal, yaitu sebagai pengganti ahli waris ayah dan ibunya yang meninggal terlebih dahulu; $b$. Pembaruan hukum yang terdapat pada Enakmen Wasiat Orang Islam di Selangor Seksyen 27 diadopsi dari Undang-Undang No. 71 Tahun 1946 tentang Wasiat di Mesir, khususnya Pasal 76-79. Selain itu, juga mengambil alih pandangan Ibnu Hazm, khususnya dalam menafsirkan al-Qur'an surat ke-2 (al-Baqarah) ayat 180, untuk menghindari kezaliman terhadap cucu yang ditutup oleh anak laki-laki. Pembaruan yang terdapat pada KHI Pasal 185 sudah menjadi living law dan telah dipraktekkan sejak ratusan tahun yang lalu. Munculnya ahli waris pengganti bermula dari Hukum Romawi yang diambil alih oleh Belanda dalam $B W$ dan diterapkan di Indonesia sehingga menjadi hukum adat. Selain itu, Hazairin berdalih bahwa ahli waris pengganti sejalan dengan al-Qurān melalui kata mawāli pada surat an-Nisa' ayat 33; c. Lingkup wasiat wajibah bersifat khusus, yaitu cucu dari anak laki-laki saja. Mereka mendapat wasiat wajibah karena termasuk ahli waris $d z a w \bar{u}$ alfurüdh dan 'ashabah. Sedangkan cucu dari anak perempuan termasuk kategori ahli waris dzawū al-arhām sehingga tidak diberi wasiat wajibah. Lingkup ahli waris pengganti bersifat umum, yaitu semua cucu dari anak laki-laki dan dari anak perempuan. Mereka menggantikan ayah atau ibu yang meninggal terlebih dahulu dari pewaris; d. Hak yang diterima cucu pada wasiat wajibah maksimal 1/3 dari harta. Namun dalam putusan mahkamah, hak cucu berkurang dari yang seharusnya diterima oleh ayah mereka sekiranya masih hidup. Hak kewarisan yang diterima cucu pada ahli waris pengganti adalah sama atau tidak boleh melebihi dari hak yang seharusnya diterima oleh ayah atau ibu mereka sekiranya masih hidup; e. Pada wasiat wajibah, status cucu dibedakan antara cucu dari anak laki-laki dan cucu dari anak perempuan. Cucu dari anak laki-laki berstatus sebagai ahli waris $d z a w \bar{u}$ al- 
furūdh dan 'ashabah. Mereka berhak mendapat wasiat wajibah. Sedangkan cucu dari anak perempuan berstatus sebagai dzawū al-arhām, sehingga tidak berhak terhadap wasiat wajibah. Sedangkan pada ahli waris pengganti tidak membedakan status cucu, baik cucu dari anak laki-laki maupun cucu dari anak perempuan. Ketentuan seperti ini sama dengan pandangan Syi'ah dan Hazairin. Akan tetapi, mazdhab Syi'ah tidak mengenal adanya ahli waris pengganti, bahkan anak perempuan menghijab semua cucu.

\section{Pola Pendistribusian Harta Kepada Cucu}

Al-Qur'ān dan Sunnah Nabi merupakan dua sumber hukum utama yang meliputi seluruh aspek kehidupan manusia.14 Amir Syarifuddin menyatakan, sebagai sumber hukum utama, al-Qur;an dari segi lafazh dan wurūd adalah qath'ī. Sedangkan dari segi dilālah, ada yang qath'ī dan ada pula yang zhannī. ${ }^{15}$

Adapun Sunnah Nabi, ada yang qath'ī dari segi wurūd dan sanādnya, yaitu kebenaran materinya datang dari Nabi dan qath'̄̄ dari segi dilālah atau penunjukannya terhadap hukum. Akan tetapi yang terbanyak adalah zhannī dari segi wurūd dan dilālah atau dari segi keduanya. ${ }^{16}$

Dalam kaitannya dengan pembaruan hukum terhadap kedua sumber hukum utama tersebut, dapat dikategorikan menjadi dua, yaitu yang membuka peluang untuk melakukan pembaruan melalui ijtihad dan yang sudah tertutup peluang untuk diperbarui. ${ }^{17}$

Aturan hukum yang tidak boleh diperbarui adalah hukum-hukum yang diketahui secara pasti dalam al-Qur'an dan Sunnah Nabi, yaitu yang bersifat qath' $\bar{\imath}$ tsubūt atau wurūd dan qath'î dilālahnya, misalnya kewajiban shalat lima waktu, puasa, zakat, keharaman zina, mencuri, dan lainnya. ${ }^{18}$ Hukum yang berpeluang untuk melakukan pembaruan adalah yang bersifat zhannī wurūd atau tsubūt dan dilālahnya. ${ }^{19}$

Ahli waris pengganti yang menjadi living law, baru dapat diterima jika tidak ada wahyu, berada di luar lingkup wahyu atau tidak bertentangan dengan

\footnotetext{
${ }^{14}$ Lihat Al-Qur'an Surat 16 ayat 89 dan Surat 6 ayat 38.

${ }_{15}$ Amir Syarifuddin, Ushul Fiqh, Jilid 1, Cetakan 4, Kencana Prenada Media Group, Jakarta, 2009, hlm. 58.

${ }^{16}$ Ibid., hlm. 120

${ }^{17}$ Ibid., hlm. 140

18Wahbah Az-Zuhayli dan Jamal Athiyah, Kontroversi Pembaruan Fiah, Erlangga, Jakarta, 2002, hlm. 113.

${ }^{19}$ Ibid., hlm. 114-115.
} 
wahyu. Keberadaan ahli waris dalam hukum Islam ditetapkan secara rinci dalam al-Qur'an dan Sunnah Nabi, dan kemudian didasarkan pula kepada ijma' ulama.

Kata mawāli pada an-Nisa' ayat 33, selain qath'ī tsubūt atau wurūd juga qath'ī dilālah. Kepastian (qath'ì dilālah) kata mawāli dibuktikan tidak adanya perbedaan pendapat para mufassir dalam menafsirkannya. Oleh sebab itu, tertutup peluang untuk mengadakan pembaruan hukum melalui ijtihad. Hukum adat juga tidak berpeluang sedikitpun untuk menggantikan nash yang sudah qath'i dilālah tersebut. Abdul Wahhaf Khallaf menyatakan bahwa ayat-ayat kewarisan termasuk kategori nash qath'î dilālah. ${ }^{20}$

Ahli waris pengganti dalam KHI juga bertentangan dengan unsur kewarisan, tanpa unsur, seperti ada pewaris mati, ada ahli waris hidup, maka tidak akan terjadi pewarisan. Akan tetapi menurut Pasal $185 \mathrm{KHI}$ : ada pewaris mati, ada ahli waris yang mati lebih dahulu dari matinya pewaris. Hal ini kelihatannya lucu, karena kalau sudah mati tentu ia bukan ahli waris. Ahli waris yang telah mati tidak akan pernah lagi disebut ahli waris.

Adanya prinsip keutamaan terhadap hak kewarisan menyebabkan pihak kerabat tertentu tertutup. Hal ini berarti bahwa hukum kewarisan Islam mengenal adanya lembaga hijab. Hijab berarti tertutupnya seseorang yang berhak menjadi ahli waris disebabkan oleh ahli waris lain yang lebih utama darinya. ${ }^{21}$ Satu diantara hijab adalah bahwa anak laki-laki menghijab semua cucu secara penuh. Sedangkan Pasal $185 \mathrm{KHI}$, cucu berhak mewarisi dikala terdapat anak laki-laki.

Ahli waris pengganti dalam KHI adalah mengubah ketentuan Allah, melanggar asas ijbari dari segi kepada siapa harta warisan itu beralih, dan memberikan hak warisan kepada orang yang telah meninggal dunia terlebih dahulu dengan upaya pengalihan kepada penggantinya. Dengan kata lain, ahli waris pengganti merupakan hasil pemikiran yang tidak dilandasi oleh keimanan, keadilan dan ketaqwaan, unsur kewarisan, dan juga tidak dilandasi oleh sistem keutamaan dan hijab.

${ }^{20} \mathrm{Abdul}$ Wahaf Khallaf, Ilmu Ushul Fiqh, Majlis al-A'la al-Islamiyah, Jakarta, 1972, hlm. 11.

${ }^{21}$ Muhammad Ali Ash-Shabuni, Rawa'u al-Bayan Tafsir Ayat al-Abkam min al-Qur'an, Jilid 2, Terj. Muhammad Hamidy dan Imron A. Manan, Bina Ilmu, Surabaya, 1985, hlm. 509 
Ulama sepakat bahwa wasiat hukumnya wajib bagi orang yang akan meninggal dunia dan meninggalkan harta yang relatif banyak. Kata kutiba dalam surat ke-2 ayat 180 berarti wajib berdasarkan qath'î dilālah. Dengan turunnya surat an-Nisa' tentang kewarisan, kemudian adanya hadits yang melarang wasiat kepada ahli waris yang berhak, maka mayoritas ulama mengubah kewajiban berwasiat itu menjadi sunat.

Sebagian ulama, seperti Imam Al-Zuhri, para fukahä' masa tabi'in, sebagian pengikut madzhab Hanbali menyatakan bahwa hulum wasiat itu tetap wajib. Pendapat ini berasal dari kalangan sahabat Nabi, seperti Ibnu Umar, Zubair, Abdullah ibn Aufa maupun Talhah. Kewajiban berwasiat tersebut ditujukan kepada ahli waris yang tidak memperoleh hak kewarisan. ${ }^{22}$ Mereka beralasan bahwa hukum yang dinasakh dari ayat itu adalah orang yang berhak mewarisi. Adapun terhadap kerabat yang terhijab atau tidak menjadi ahli waris, kewajiban tersebut masih tetap ada. Al-Jasas memperkuat lagi bahwa kata kutiba maknanya furidha, kemudian ditambah lagi dengan kata ma'ruf dan taqwa merupakan kata yang sangat kuat menunjukkan kepada wajib, karena Allah menjadikan wasiat itu sebagai salah satu syarat ketaqwaan. ${ }^{23}$

Para fukahā tabi'in, Imam-imam hadits dan fiqh, seperti Said al-Musayyab, Adh-Dhuhāk,Thāwus, Al-Hasanul Bishri, Ahmad ibn Hanbal, Daud bin Ali, Ishaq ibn Rawahaih, Ibnu Jarir, dan lainnya mengatakan bahwa wasiat untuk para kerabat terdekat yang tidak mendapat bagian kewarisan adalah wajib. ${ }^{24}$ Abdullah ibnu Abbas (salah seorang sahabat Nabi) mengatakan bahwa al-Qur'an surat ke-2 (al-Baqarah) ayat 180 adalah ayat muhkamat yang tetap berlaku hukumnya. Artinya, bahwa wasiat itu hukumnya wajib diberikan kepada keluarga yang tidak mendapat kewarisan. ${ }^{25}$

Menurut surat al-Baqarah ayat 180-182, secara tegas menyatakan bahwa hukum wasiat adalah wajib. Para mufassir kelihatannya tidak ada yang mempersoalkan hal tersebut karena ayat kewajiban berwasiat itu sangat jelas dan

${ }^{22}$ Sayyid Sabiq, Figh Sunnah, Juz III, Daar al-Kitab al-Arabi, Libanon, 1971, hlm. 416-417.

${ }^{23}$ Abu Bakar al-Jasas, Ahkam al-Qur'an, Jilid 2, Daar al-Kitab, Beirut, tanpa tahun, hlm. 164. hlm. 261.

${ }^{24}$ T. Muhammad Hasbi Ash-Shieddiqy, Fiqh Mawaris, Cetakan 2, Pustaka Rizki Putra, Semarang, 2010, ${ }^{25} \mathrm{Ibid}$, hlm. 262-263. 
tegas (qath'î dilālah) ditujukan kepada pemilik harta. Pada ujung ayat dikuatkan lagi bahwa berwasiat itu menjadi kewajiban bagi orang yang bertaqwa.

Kewajiban berwasiat juga diperkuat oleh Sunnah Nabi SAW. Di antaranya terdapat dua hadits yang diriwayatkan oleh Ibnu Majah sebagai berikut:

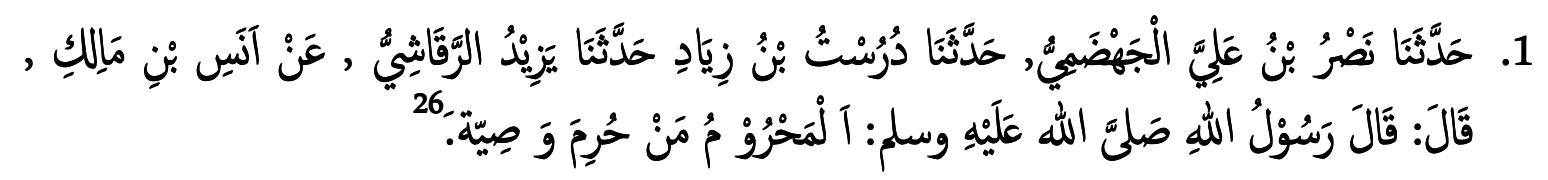

Artinya: Telah menceritakan Nashr bin Ali al-Jahdhami, Durust bin Ziyad, Yazid bi al-Raqasyi, dari Anas bin Malik berkata dia, Rasulullah SAW bersabda: Orang yang bernasib buruk (merugi) ialah orang yang tidak sempat berwasiat.

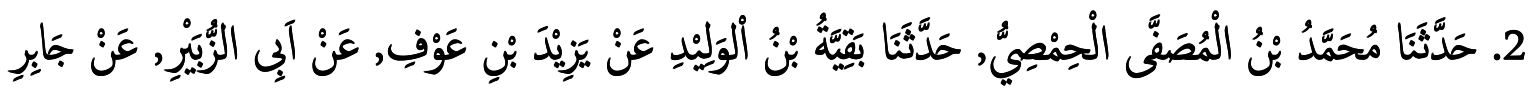

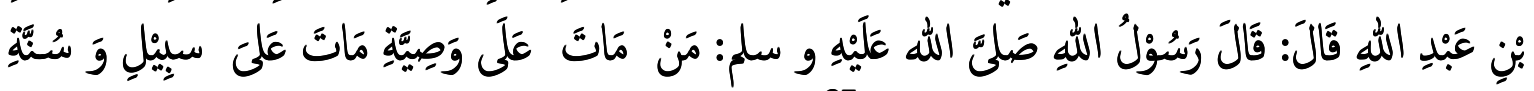

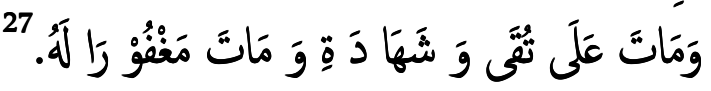

Artinya: Menceritakan Muhammad bin al-Mushaffa al-Himshi, Baqiiyah bin alWalid dari Yazid bin Auf, dari Abi Zubair, dari Jabir bin Abdullah berkata dia; Rasulullah SAW bersabda: Barangsiapa yang meninggal dunia dengan meninggalkan wasiat maka dia meninggal di atas jalan ini dan sunnah. Dia meninggal dalam keadaan taqwa dan dipersaksikan serta meninggal dalam keadaan diampunkan dosanya.

Ulama sepakat bahwa berwasiat kepada selain kerabat hukumnya tidak wajib, dan sudah semestinya berwasiat kepada kerabat hukumnya wajib. Qatadah (sahabat Nabi) mengatakan bahwa:

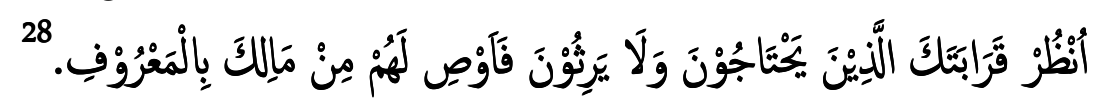

Pendistribusian harta kepada cucu yang kematian orang tua perlu penguatan teoretis dalam metodologi hukum Islam untuk memperkuat eksistensi melalui Enakmen Wasiat Orang Islam. Al-Qur'an (4:7) menyatakan bahwa:

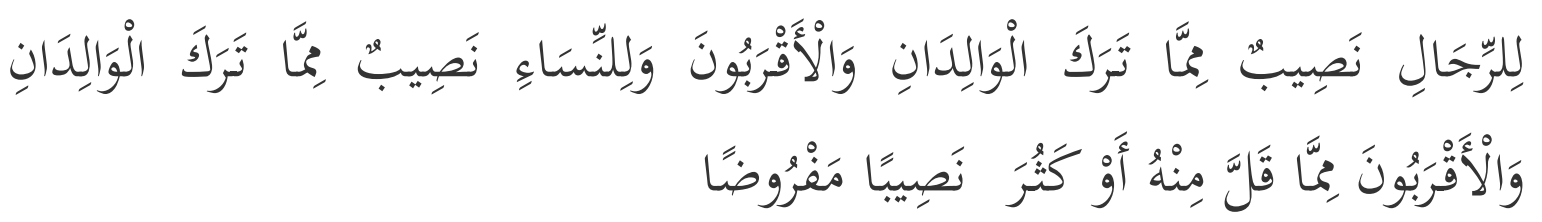

${ }^{26}$ Imam al-Hafidz Abi Abdullah bin Yazid al-Qazwayni (Ibnu Majah), Sunan Ibnu Majah, Juz II, AlMaktabah al-'Ashariyah, Beirut, 2006, hlm. 472-473.

${ }^{27} \mathrm{Ibid}$, hlm. 474.

${ }^{28}$ Ibid. 
Lafazh al-Aqrabūn berarti kerabat yang mempunyai hubungan darah dengan pewaris dan mendapatkan harta warisan. Berdasarkan mafhūm muwäfaqah, cucu yang kematian orang tuanya lebih dahulu dari pewaris wajib diberi harta karena di antara mereka juga berhubungan darah. Selain itu, mereka juga berstatus sebagai yatim.

Kewajiban berwasiat ditujukan kepada ahli waris dan kerabat yang tidak berhak mewarisi karena sesuatu hal, seperti ditutup oleh ahli waris yang lebih utama maupun karena mereka termasuk kategori dzawū al-arhām. Sayyid Quthb menegaskan bahwa al-Qur'an surat ke-4 ayat 8 adalah muhkamat dan menunjukkan hukum wajib untuk memberikan bagian kepada $\bar{u} l \bar{u}$ al-qurbā yang tidak berhak mewarisi. ${ }^{29}$ Ibnu Abbas juga mengatakan wajib. ${ }^{30}$

Al-Maraghi mengatakan bahwa maksud $\bar{u} l \bar{u}$ al-qurbā surat ke-4 ayat 8 ialah orang-orang dari kalangan kerabat pewaris yang tidak berhak mewarisi. Mereka itu diberi rezeki dari harta warisan sebelum diadakan pembagian. Rahasia yang terkandung dalam perintah memberi sebagian harta warisan itu karena kemungkinan kedengkian menyusupi dada mereka. ${ }^{31}$

Wasiat wajibah yang ditujukan kepada cucu laki-laki dan perempuan dari ayah mereka, bila dikaitkan dengan lafazh $\bar{u} l \bar{u}$ al-qurbā, tidaklah tepat. Wasiat wajibah harus ditujukan kepada kerabat atau $\bar{u} l \bar{u}$ al-qurbā. Hal yang sama juga diungkap oleh Qatadah (sahabat Nabi) yang memerintahkan untuk berwasiat kepada karib kerabat. Secara tathbiqi, tidak ada dalil yang mengkhususkan bahwa wasiat itu hanya untuk cucu dari pihak laki-laki saja. Oleh sebab itu, sudah sepatutnya cucu dari pihak perempuan juga mendapat wasiat wajibah. Cucu yang diberi wasiat diutamakan yang seiman, karena selain berhubungan darah juga berhubungan aqidah.

Bagian yang diterima cucu dalam wasiat wajibah di Selangor, adalah dua banding satu antara laki-laki dan perempuan, yaitu mengikuti pembagian kewarisan dalam surat an-Nisa' ayat 11. Sistem pembagian wasiat wajibah antara laki-laki dan perempuan memang tidak diatur secara tegas dalam wahyu. Hal ini

\footnotetext{
${ }^{29}$ Sayyid Quthb, Tafsir fi Zhilal al-Qur'an, Jilid 2, Dar al-Syuruq, Beirut, 1992, hlm. 186.

${ }^{30}$ Jalaluddin al-Suyuthi dan Jalaluddin al-Mahalli, Tafsir Jalalain, Jilid 1, Alihbahasa Bahrun Abu Bakar, Sinar Baru Algesindo, Bandung, 2011, hlm. 326-327.

${ }^{31}$ Ibid., hlm. 346.
} 
berarti terbuka peluang untuk melakukan ijtihad yang sejalan dengan kemaslahatan dan keadilan.

Status wasiat wajibah dapat dilihat dari dua aspek, yaitu waris dan wasiat. Dari sisi waris, bahwa peralihan harta kepada ahli waris sama dengan peralihan harta pewasiat kepada penerima wasiat, yaitu bersifat ijbari, yaitu keterpaksaan pemilik harta untuk melepaskan hartanya karena sudah meninggal dunia, dan keterpaksaan ahli waris atau penerima wasiat untuk menerima harta pewaris/pewasiat. Bila dilihat dari segi wasiat, disebabkan konsepnya wasiat. Sebagai wasiat, seharusnya hak yang diterima tidak dibedakan antara laki-laki dan perempuan.

\section{Penutup}

Hak cucu yang tertutup dalam fiqh mujtahid terdahulu, diperbarui dalam fiqh perundang-undangan di Selangor dan Indonesia. Di Selangor, hak cucu untuk mendapatkan harta kakek/nenek disebut wasiat wajibah, dan di Indonesia disebut dengan ahli waris pengganti. Terdapat beberapa persamaan dan perbedaan antara wasiat wajibah dengan ahli waris pengganti.

Keberadaan wasiat wajibah menurut Enakmen Wasiat Orang Islam di Selangor, Malaysia merupakan hasil ijtihad tatbiqi yang sejalan dengan prinsip alQur'an dan Sunnah Nabi. Cucu dari pihak laki-laki yang kematian orang tuanya lebih dahulu dari pewaris menerima wasiat wajibah. Sedangkan cucu dari pihak perempuan tidak diberi wasiat wajibah. Bagian yang diterima cucu dapat ditetapkan dalam status waris maupun sebagai wasiat sejalan dengan kemaslahatan dan keadilan.

Ahli waris pengganti dirumuskan melalui jalur yurisprudensi yang bersumber dari hukum adat. Ahli waris pengganti dalam hukum adat adalah adopsi dari hukum perdata Belanda. Adapun hukum perdata Belanda berasal dari Code Civil Napoleon di Perancis. Hukum perdata Perancis merupakan turunan dari hukum Romawi. Ahli waris pengganti merupakan budaya yang tidak dilandasi oleh keimanan (syahadat), bertentangan dengan prinsip keadilan, asas 
ijbari, tidak sejalan dengan unsur-unsur kewarisan dan juga bertentangan dengan prinsip keutamaan dan hijab.

Direkomendasikan kepada pihak yang berwenang memperbaharui Enakmen Wasiat Orang Islam, khususnya Seksyen 27 tentang wasiat wajibah yang ditujukan kepada semua cucu yang orang tuanya meninggal dunia lebih dahulu dari kakek dan nenek. Sedangkan keberadaan ahli waris pengganti dalam KHI Pasal 185 perlu ditinjau ulang.

\section{Daftar Pustaka}

Al-Qur'an Al-Karim

Abdul Halim, Wan bin Wan Harun, "Isu-Isu Pembahagian Harta Pusaka dalam Konteks Perundang-undangan, dalam Jurnal Penguasaan Jawhar, Vol. 3 No. $1,2009$.

Abdurrahman, Kompilasi Hukum Islam di Indonesia, Akademika Pressindo, Jakarta, 2004.

Ali Ash-Shabuni, Muhammad, Rawa'u al-Bayan Tafsir Ayat al-Ahkam min alQur'an, Jilid 2, Terj. Muhammad Hamidy dan Imron A. Manan, Bina Ilmu, Surabaya, 1985.

Badly, Mahmud Muhammad, Pengurusan dan Penyelewengan Harta dalam Pandangan Islam, Dinie Publisher, Kuala Lumpur, 1994.

Hafidz Abi Abdullah bin Yazid al-Qazwayni, Imam, (Ibnu Majah), Sunan Ibnu Majah, Juz II, Al-Maktabah al-'Ashariyah, Beirut, 2006.

Hasbi Ash-Shieddiqy, T. Muhammad, Figh Mawaris, Cetakan 2, Pustaka Rizki Putra, Semarang, 2010.

Ibrahim, Ahmad, Undang-Undang Keluarga Islam di Malaysia, Lexis Nexis, Kuala Lumpur, 2011.

Jasas, al, Abu Bakar, Ahkam al-Qur'an, Jilid 2, Daar al-Kitab, Beirut, tt.

Komite Fakultas Syariah Universitas Al-Azhar, Ahkam al-Mawarits fi al-Fiqh alIslami, Cetakan 1, terj. Addys Aldizar dan Fathurrahman, Senayan Abadi Publishing, Jakarta, 2004.

Masrani, Basran, "Kompilasi Hukum Islam", dalam Mimbar Ulama, No. 104 Tahun X, 1986.

Muda, Mohd. Zamro, "Instrumen Hibah dan Wasiat: Analisis Hukum dan Aplikasinya di Malaysia, kertas kerja dibentangkan di Bengkel Hibah, Sekyen Syariah jabatan Peguam Negara, Hotel Equatonial, 18-19 November 2008. 
Quthb, Sayyid, Tafsir fi Zhilal al-Qur'an, Jilid 2, Dar al-Syuruq, Beirut, 1992.

Rofiq, Ahmad, Pembaharuan Hukum Islam di Indonesia, Cet. 1, Gama Media, Yogyakarta, 2001.

Sabiq, Sayyid, Fiqh Sunnah, Juz III, Daar al-Kitab al-Arabi, Libanon, 1971.

Siddik, Abdullah, Hukum Waris Islam dan Perkembangannya di Seluruh Dunia Islam, Wijaya, Jakarta, 1984.

Sulong, Jasni, "Kedudukan Madzhab Syafi'i dalam Amalan Pembagian Pusaka dan Wasiat di Malaysia", Shari'ah Journal, Vol. 16 Nomor 1, 2008.

Suyuthi, al, Jalaluddin, dan Jalaluddin al-Mahalli, Tafsir Jalalain, Jilid 1, Alihbahasa Bahrun Abu Bakar, Sinar Baru Algesindo, Bandung, 2011.

Syarifuddin, Amir, Ushul Fiqh, Jilid 1, Cetakan 4, Kencana Prenada Media Group, Jakarta, 2009.

Wahaf Khallaf, Abdul, Ilmu Ushul Figh, Majlis al-A'la al-Islamiyah, Jakarta, 1972.

Yurisprudensi Mahkamah Agung di Indonesia, 2009.

Yurisprudensi Mahkamah Tinggi Syariah di Selangor, Malaysia, 2013.

Yurisprudensi Pengadilan Tinggi Agama Riau, Pekanbaru, 2012.

Zuhayli, az, Wahbah, dan Jamal Athiyah, Kontroversi Pembaruan Fiah, Erlangga, Jakarta, 2002. 